\title{
Determination of Cell Potential for Silicon Electrodeposition
}

\author{
SAMIRA SOKHANVARAN, ABDOLKARIM DANAEI, and MANSOOR BARATI
}

\begin{abstract}
Electrowinning of Si from cryolite-based melts is a possible solution for mass production of high purity silicon. The required cell potential to deposit $\mathrm{Si}$ on a cathode of interest, copper, is fundamental information that needs to be measured for controlling the co-deposition of impurities. In this study, the potential was measured using cyclic voltammetry in a cryolite- 6 pct $\mathrm{SiO}_{2}$ melt. The deposited $\mathrm{Si}$ on copper forms a Cu-Si alloy in which the activity of $\mathrm{Si}$ affects the decomposition potential. The measurements were carried out in a range of Si concentrations, allowing the prediction of potential change during the actual deposition process, where the $\mathrm{Si}$ content changes constantly. The results were compared with the values obtained from cyclic voltammetry on an inert electrode, graphite, to investigate if the formation of $\mathrm{Cu}-\mathrm{Si}$ alloy is responsible for decreasing the potential.
\end{abstract}

DOI: $10.1007 / \mathrm{s} 40553-014-0019-4$

(c) The Minerals, Metals \& Materials Society and ASM International 2014

\section{INTRODUCTION}

THERE is a great momentum to shift our fuel-based energy dependence towards the alternative renewable sources. One of the most abundant renewable energies is solar power with a potential to far surpass the total energy demand of the world. However, the high cost of this energy has been the main hurdle against its widespread usage. Silicon is the chief photovoltaic material that accounts for 25 to 50 pct of the cost of solar panels. Traditionally, the majority of silicon for solar industry was supplied from overcapacity, scraps, and rejects of the semiconductor industry. The semiconductor grade $\mathrm{Si}$ requires excessive purity $(9 \mathrm{~N})$ and costs around $\$ 250 \mathrm{~kg}^{-1} \cdot{ }^{[1]}$ On the other hand, 6 to $7 \mathrm{~N}$ is the acceptable range of purity for solar application and further purification is not necessary. Therefore, a new type of silicon known as solar-grade silicon (SoG-Si) was introduced, for which the target price is $\$ 10$ to $15 \mathrm{~kg}^{-1} \cdot[2,3]$ The current price is about $\$ 18 \mathrm{~kg}^{-1},[4]$ down from over $\$ 200 \mathrm{~kg}^{-1}$ in 2008 .

The existing method for production of solar grade $\mathrm{Si}$ (SoG-Si) necessitates a two-step process: producing metallurgical-grade $\mathrm{Si}$ (MG-Si) by carbothermal reduction of $\mathrm{SiO}_{2},{ }^{[5]}$ followed by the CVD-based purification method (Siemens). Although this technique requires high energy consumption (120 to $\left.200 \mathrm{kWh} \mathrm{kg}^{-1}\right)$ and massive environmental impacts $\left(90 \mathrm{t} \mathrm{CO}_{2} / \mathrm{t} \mathrm{Si}\right),{ }^{[6]}$ it is still utilized in producing 95 pct of SoG-Si in the market. Thus, the need for developing a technology with higher productivity and lower energy intensity is

SAMIRA SOKHANVARAN, Ph.D. Candidate, and MANSOOR BARATI, Associate Professor, are with the Department of Materials Science and Engineering, University of Toronto, Suite 140, 184 College Street, Toronto, ON M5S 3E4, Canada. Contact e-mail: samira.sokhanvaran@mail.utoronto.ca ABDOLKARIM DANAEI, Ph.D. Candidate, is with the Department of Mechanical and Industrial Engineering, Ryerson University, 350 Victoria Street, Toronto, ON M5B 2K3, Canada.

Manuscript submitted October 23, 2013.

Article published online April 22, 2014 important. The feasibility of developing this alternative method has been investigated by numerous research groups in the past two decades. However, their achievements are limited to laboratory and pilot scale ${ }^{[7,8]}$ and not successful in commercial scale. The electrolytic approach has been proven to be a successful silicon producing method due to its analogy with other elements in the periodic table namely aluminum; though this approach remains relatively understudied.

Decomposition potential is the minimum potential required for continuous electrolysis ${ }^{[9]}$ and is one of the parameters that has to be measured to predict the required cell voltage and the possibility and order in which other elements are reduced. The standard decomposition potential of $\mathrm{SiO}_{2}$ has been calculated from the Nernst's equation as $-1.75 \mathrm{~V}$ at $1313 \mathrm{~K}$ $\left(1040{ }^{\circ} \mathrm{C}\right) \cdot{ }^{[3,10,11]}$ In most of the researches, graphite has been used as the anode due to its resistance to the corrosive environment of molten salts. Graphite reacts with the evolved $\mathrm{O}_{2}$ and results in the release of $\mathrm{CO}$ and $\mathrm{CO}_{2}$ on the anode surface. The reactions decrease the theoretical decomposition potential to -0.73 and $-0.57 \mathrm{~V}$ for $\mathrm{CO}_{2}$ and $\mathrm{CO}$ release, respectively. ${ }^{[1]}$

The experimentally measured deposition potentials ${ }^{[12-20]}$ are considerably different from these calculated values. For example, the decomposition potential on graphite cathode has been reported between -0.80 and $-1 \mathrm{~V}^{[12-20]}$ which is approximately $0.25 \mathrm{~V}$ larger than the predicted potential. According to Boe et al. ${ }^{[13]}$ this difference is mainly due to the polarization and concentration overpotential. However, applying cyclic voltammetry by Boen et al., ${ }^{[20]}$ Osen et al., ${ }^{[19]}$ and Ming et al. ${ }^{[21]}$ revealed two-step reduction of $\mathrm{Si}^{4+}$ in the alkaline fluoride melts. This method also enabled measuring the deposition potential of $\mathrm{Si}$ on a graphite cathode that is reported to be approximately $-0.8 \mathrm{~V} v \mathrm{Ag}$ electrode. ${ }^{[20]}$

Cryolite-based salts have been reported as the most suitable electrolyte for electrolysis of the silicon with respect to the product purity and current efficiency. ${ }^{[22-25]}$ The main focus of this study is to determine the decomposition potential of $\mathrm{Si}$, from cryolite- $\mathrm{SiO}_{2}$ melt 
on a $\mathrm{Cu}$ cathode, using cyclic voltammetry. The reason for using copper as cathode is to form a liquid alloy with silicon, thus eliminating the possibility of forming powdery solid $\mathrm{Si}$, also to increase the current density. The Si could then be recovered using methods described elsewhere. ${ }^{[8]}$ According to the Nernst equation the decomposition potential is a function of the activity of $\mathrm{Si}$ in cathode:

$$
\mathrm{SiO}_{2}(\mathrm{~s}) \rightarrow \mathrm{Si}(\mathrm{s})+\mathrm{O}_{2}(\mathrm{~g}) \quad \Delta G_{1313 \mathrm{~K}\left(1040^{\circ} \mathrm{C}\right)}^{\mathrm{o}}=676.2 \mathrm{~kJ},
$$

$$
E_{\mathrm{T}}=E_{\mathrm{T}}^{\mathrm{o}}-R T \ln \left(\frac{a_{\mathrm{Si}} \cdot P_{\mathrm{O}_{2}}}{a_{\mathrm{SiO}_{2}}}\right) .
$$

During electrowinning, the deposited $\mathrm{Si}$ dissolves in molten $\mathrm{Cu}$ cathode and forms a $\mathrm{Cu}-\mathrm{Si}$ alloy. Theoretically, increase in the concentration and as a result the activity of $\mathrm{Si}$ in the alloy pushes the required potential to more negative values. This means that for continuous electrolysis, the potential should be adjusted and larger overpotentials should be applied. This effect was investigated experimentally and the results are presented in this paper. These results are also compared with the deposition potential of $\mathrm{Si}$ on an inert cathode, graphite, where the activity of $\mathrm{Si}$ is equal to 1 .

\section{EXPERIMENTAL}

\section{A. Chemicals}

Cyclic voltammetry was conducted in $100 \mathrm{gr}$ of $\mathrm{SiO}_{2}-$ $\mathrm{Na}_{3} \mathrm{AlF}_{6}$ electrolytes containing 6 wt pet of $\mathrm{SiO}_{2}$. Natural cryolite (supplied by Rio Tinto-Alcan) with $\mathrm{Na}$ :Al ratio of 3.3 and total impurity content of $0.6 \mathrm{wt}$ pet was ground into fine powders to pass a $104 \mu \mathrm{m}$ sieve. Silica with a purity of 99.5 pct and mean particle size of $2 \mu \mathrm{m}$ was used. Both powders were heated in an oven to $423 \mathrm{~K}\left(150^{\circ} \mathrm{C}\right)$ to eliminate moisture and other volatile impurities.

\section{B. Cell Assembly}

A schematic drawing of the complete cell assembly is presented in Figure 1. A vertical tube furnace equipped with a digital controller was used to heat up the cell to $1313 \mathrm{~K}\left(1040{ }^{\circ} \mathrm{C}\right)$. The cell was held in an alumina tube to protect the wall of the furnace and the heating elements from corrosive atmosphere. All the experiments were conducted under an inert atmosphere using dried argon gas. The flow rate of the inlet gas was

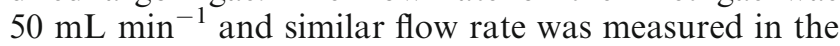
outlet to assure that the system is fully sealed.

The cell consists of two electrodes: a copper disk (25 $\mathrm{mm}$ diameter and $5 \mathrm{~mm}$ height) as the working electrode, and a graphite rod $(6.35 \mathrm{~mm}$ diameter $)$ as the counter electrode. All the electrodes were attached to Mo leads (wires of $2 \mathrm{~mm}$ diameter) that were extended out of the cell to be connected to the potentiostat. All the lead wires were sheeted in alumina tubes to prevent

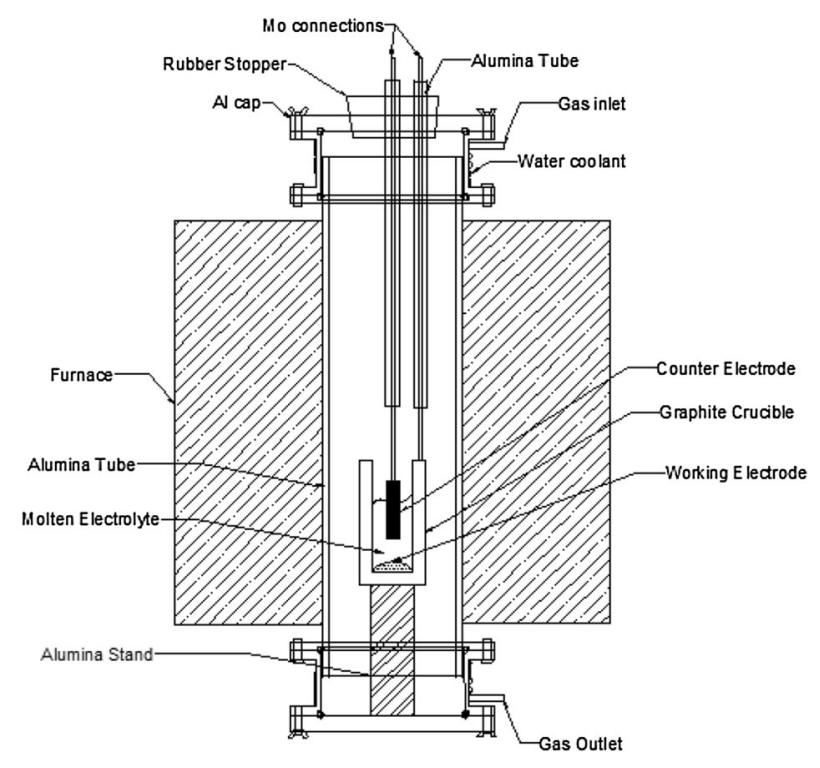

Fig. 1-Schematic experimental setup.

short circuiting and protect them from corrosive gases. When the melt reached equilibrium, the counter electrode was lowered to touch the melt surface. The melt level was detected by chronoamperometry technique. Then, it was immersed $20 \mathrm{~mm}$ into the molten salt.

The electrode potentials were controlled with a 1287 Solartron Potentiostat connected to a computer with a CorrWare software. Cyclic voltammetry was performed for a potential range of -1.25 to $0.3 \mathrm{~V}$, considering the reported decomposition potential for silica. Different scan rates $\left(5-10-20-50-80-100 \mathrm{mV} \mathrm{s}^{-1}\right)$ were applied to investigate the kinetics of oxidation and reduction reactions. To study the effect of $\mathrm{Si}$ concentration on the deposition potential, the melt was electrolyzed twice, each time for 20 minutes at $-1.2 \mathrm{~V}$; resulting in changing the concentration of $\mathrm{Si}$ on the surface of $\mathrm{Cu}$ electrode. Then, cyclic voltammetry experiments were repeated after each deposition to study the shift of potential and the variation in kinetics. A blank test was first performed in pure cryolite melt to enable recognition of background peaks resulting from the electrolyte.

These results were compared with the measured deposition potential on a graphite electrode as an inert cathode. Finally, similar experiment was run on the surface of 5 gr Cu- 8 wt pet Si alloy. This alloy in molten at $1313 \mathrm{~K}\left(1040{ }^{\circ} \mathrm{C}\right)$ and will provide the exact potential that is required for continuous deposition of $\mathrm{Si}$ on the surface of this alloy.

\section{RESULTS AND DISCUSSION}

\section{A. Cyclic Voltammetry on Graphite}

Initially, cyclic voltammetry was conducted on an inert cathode (graphite) to measure the required potential at which the cathodic half reaction commences at graphite electrode. The deposition potential was measured $v s \mathrm{Pt}$ as a quasi-reference electrode. The 
experimental setup was similar to what was explained for copper cathode. The only differences in the setup were the working electrode, which was a graphite rod $(6.35 \mathrm{~mm}$ diameter), the counter electrode, which was graphite crucible, and the concentration of $\mathrm{SiO}_{2}$ in cryolite. The detailed experimental procedure is provided in previous publications. ${ }^{[10,26]}$ A typical voltammograms recorded with two different scan rates, in cryolite-5 wt pct $\mathrm{SiO}_{2}$ at $1313 \mathrm{~K}\left(1040{ }^{\circ} \mathrm{C}\right)$, is shown in Figure 2. Major cathodic and corresponding anodic peaks form due to $\mathrm{Si}$ deposition and re-oxidation. At lower scan rate, Figure 2(a), the reduction reaction starts at $-0.65 \mathrm{~V}$ and reach its maximum at $-1 \mathrm{~V}$. The presence of the corresponding anodic peak at around $-0.1 \mathrm{~V}$ indicates that silicon can be cathodically deposited and anodically oxidized. The shape of the voltammogram confirms that this reaction is not reversible. However, the major cathodic peak is a combination of two small peaks, indicating multi-stage reduction of $\mathrm{Si}$ on graphite, which is also confirmed by the formation of an anodic shoulder on the main peak. According to Ming et al. ${ }^{[21]}$ the main peak is due to:

$$
\mathrm{Si}^{4+}+2 \mathrm{e}^{-} \rightarrow \mathrm{Si}^{2+}
$$

and the post-peak is due to the actual silicon formation:

$$
\mathrm{Si}^{2+}+2 \mathrm{e}^{-} \rightarrow \mathrm{Si}
$$

These two peaks have a similar current intensity that corresponds to similar rate constant of the reactions at scan rate as low as $20 \mathrm{mV} \mathrm{s}^{-1}$. While the recorded voltammogram at higher scan rate, $50 \mathrm{mV} \mathrm{s}^{-1}$ shown in Figure 2(b), illustrates two completely separate peaks: the first peak at $-0.7 \mathrm{~V}$ is elongated and the second one at $-1 \mathrm{~V}$ is hindered. This brings the conclusion that the second reaction has a slow kinetics and is likely the rate determining step. At higher scan rates $\left(50 \mathrm{mV} \mathrm{s}^{-1}\right)$; the progress of this reaction is very limited. Whereas, at lower scan rates $\left(20 \mathrm{mV} \mathrm{s}^{-1}\right)$, this reaction has enough time to proceed and the two steps occur at a comparable rate.

\section{B. Voltammetry Measurements on Copper}

In the following sections, the effect of changing cathode to $\mathrm{Cu}$ will be discussed. $\mathrm{Cu}$ will form a liquid cathode with Si that is expected to change the kinetics of electrolysis, as well as the deposition potential by decreasing the activity of $\mathrm{Si}$.

\section{Cyclic Voltammetry in Cryolite}

As a blank test and to eliminate possible background peaks later, cyclic voltammogram were recorded before any $\mathrm{Si}^{4+}$ were introduced to the system as $\mathrm{SiO}_{2}$. The potential was varied in the cathodic direction from $0.5 \mathrm{~V}$ and was reversed at $-1.2 \mathrm{~V}$ to determine the electrochemical behavior of the melt. The recorded voltammograms are shown in Figure 3.

From the figure it is seen that decomposition of cryolite starts approximately at $-0.6 \mathrm{~V}$. This peak is attributed to irreversible $\mathrm{Na}$ deposition as no broad oxidation peak is observed in the oxidation cycle. As the working temperature of the cell was above the boiling temperature of $\mathrm{Na} 1156 \mathrm{~K}\left(883^{\circ} \mathrm{C}\right)$, evaporation of the deposited $\mathrm{Na}$ occurs and the oxidation peak is less prominent. Deposition of $\mathrm{Al}$ is also reported in cryolite, ${ }^{[21,27]}$ and can be a reason for the serration of the graph at larger overpotential. Oxidation of copper was observed at around $0.4 \mathrm{~V}$, which dictated the anodic range of the potential window.

\section{Cyclic Voltammetry in Cryolite-6 wt pet $\mathrm{SiO}_{2}$ Melt}

Cyclic voltammogram for deposition and subsequent dissolution of $\mathrm{Si}$ on a copper electrode were recorded within the potential range of 0.3 to $-1.4 \mathrm{~V}$. Cyclic voltammetry in of molten cryolite on a copper electrode shows that copper oxidation starts at $0.3 \mathrm{~V}$, Figure 3(a),

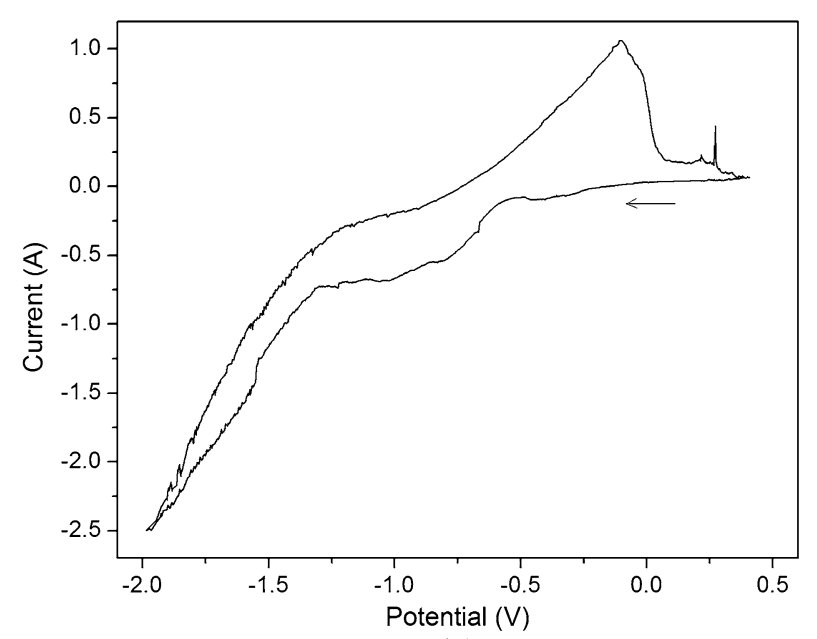

(a)

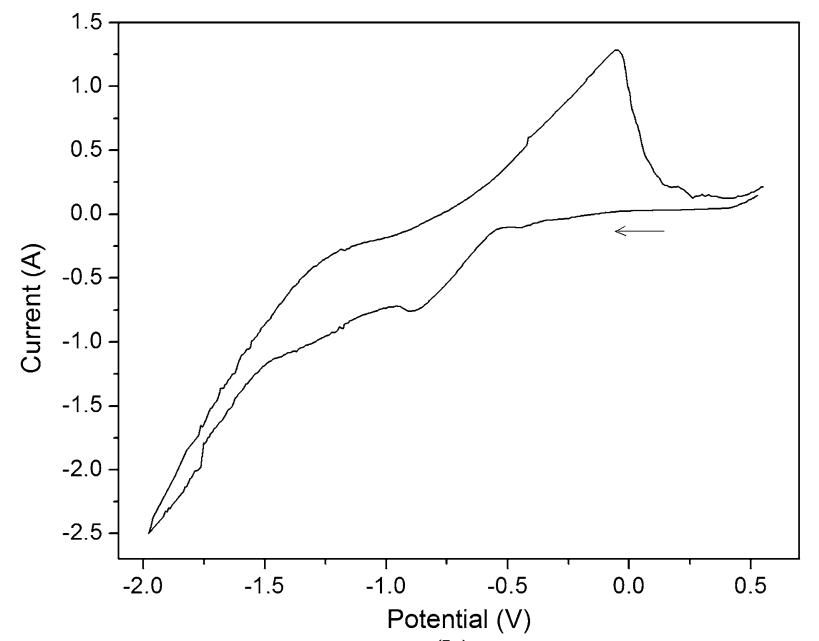

(b)

Fig. 2-Typical voltammogram recorded on a graphite cathode $v s$ Pt reference in cryolite-5 wt pct $\mathrm{SiO}_{2}$ melt at $1313 \mathrm{~K}\left(1040{ }^{\circ} \mathrm{C}\right)$; $(a)$ scan rate $20 \mathrm{mV} \mathrm{s}^{-1},\left(\right.$ b) scan rate $50 \mathrm{mV} \mathrm{s}^{-1}$. 


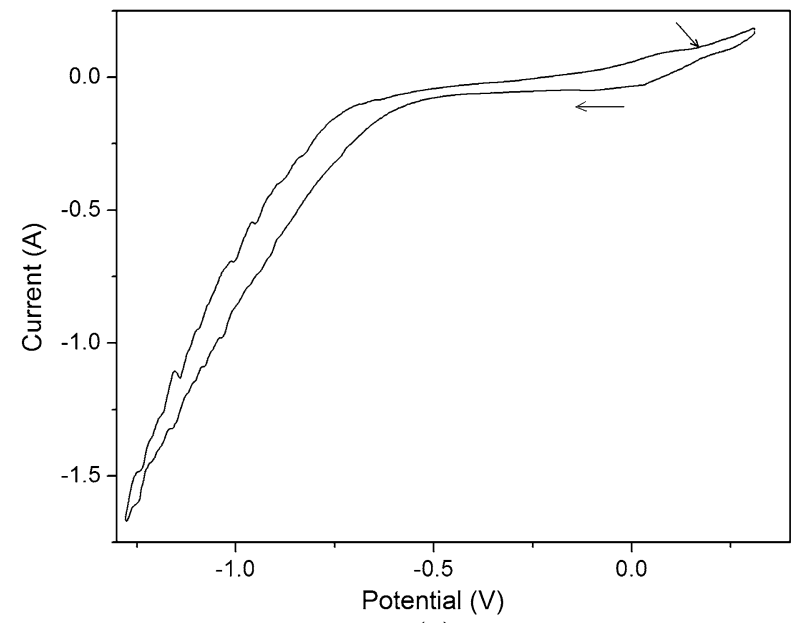

(a)

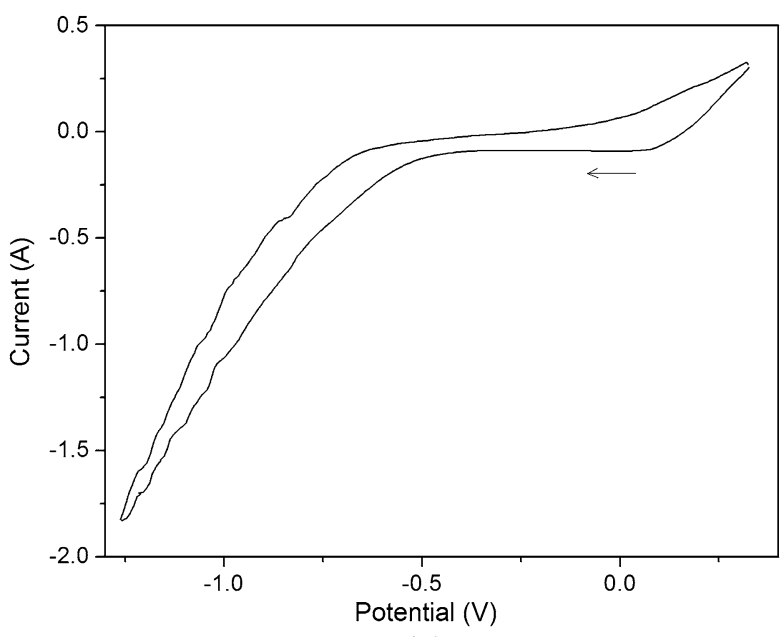

(b)

Fig. 3-(a) Voltammogram in molten $\mathrm{SiO}_{2}$-free cryolite; $20 \mathrm{mV} \mathrm{s}^{-1}$, (b) Voltammogram in molten $\mathrm{SiO}_{2}$-free cryolite; $50 \mathrm{mV} \mathrm{s}^{-1}$.

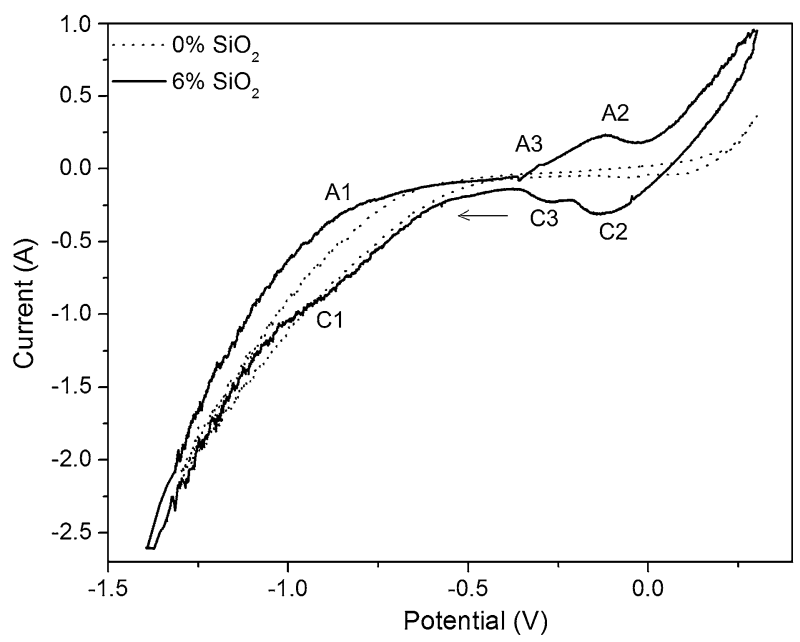

Fig. 4-Voltammogram for deposition of $\mathrm{Si}$ on copper in molten cryolite- 6 wt pet $\mathrm{SiO}_{2} ; 10 \mathrm{mV} \mathrm{s}^{-1}$.

therefore the anodic potential limit was set below this value to avoid the oxidation of the copper electrode. The cathodic limit was set to observe a deposition peak and tolerate the current limit of the potentiostat.

Figure 4 shows a typical cyclic voltammogram obtained on the copper electrode for $\mathrm{Si}^{4+}$ reduction in a cryolite system with 6 wt pct $\mathrm{SiO}_{2}$ at $1313 \mathrm{~K}$ $\left(1040{ }^{\circ} \mathrm{C}\right)$. This voltammogram is compared with the recorded voltammogram in cryolite at the same scan rate, $10 \mathrm{mV} \mathrm{s}^{-1}$. As seen, bulk deposition of $\mathrm{Si}\left(\mathrm{C}_{1}\right)$ commences from $-0.6 \mathrm{~V}$ with a maximum rate at $-1 \mathrm{~V}$. This potential is less cathodic than the equilibrium potential predicted by the Nernst equation. However, it is in good agreement with the presented potential by Grjotheim et al. ${ }^{[13]}$ His results reports $-1.1 \mathrm{~V}$ as the cell potential for deposition of $\mathrm{Si}$ on $\mathrm{Cu}$. Peak identified as $\mathrm{A}_{1}$ in the reverse cycle corresponds to the stripping of electrodeposited Si. The charge consumed for the current rise at $-1 \mathrm{~V}$ is much greater than the corresponding anodic peak. This difference in current indicates that considerable amount of current is consumed by irreversible solvent decomposition (as seen in Figure 3).

Two minor reversible peaks $\left(\mathrm{C}_{2}\right.$ and $\left.\mathrm{A}_{2}\right)$ are also observed at potentials below that for bulk deposition of $\mathrm{Si}$. These peaks are related to the under-potential deposition (UPD) and subsequent oxidation of $\mathrm{Si}$. UPD is mainly because of adsorption of $\mathrm{Si}$ ions on $\mathrm{Cu}$ substrate $\left(\mathrm{Si}_{\text {solv }}^{4+}+4 \mathrm{e}_{\mathrm{Cu}}=\mathrm{Si}_{\mathrm{ad}, \mathrm{Cu}}\right) \cdot{ }^{[28,29]}$ This phenomenon can only happen if the activity of the product in the cathode is less than unity. Besides the bulk deposition and UPD peaks, another cathodic peak $\left(\mathrm{C}_{3}\right)$ also exists in this voltammogram. The most plausible explanation for this neighbor peak seems to be interaction between $\mathrm{Cu}$ and $\mathrm{Si}$, and formation of $\mathrm{Cu}-\mathrm{Si}$ alloy. As soon as $\mathrm{Si}$ deposits on the surface of $\mathrm{Cu}$ electrode a molten layer of $\mathrm{Cu}-\mathrm{Si}$ alloy forms on the surface. At $1313 \mathrm{~K}\left(1040{ }^{\circ} \mathrm{C}\right)$, to form a liquid, approximately $4 \mathrm{pct}$ $\mathrm{Si}$ must be present in the cathode, which can be achieved at the surface rather quickly. In the anodic scan, a very small reduction peaks $\left(\mathrm{A}_{3}\right)$ appears, which corresponds to de-alloying of Si from the surface before stripping of $\mathrm{Si}$.

\section{E. Effect of Scan Rate}

To investigate the kinetics of the reduction reaction, the reaction was studied over a wide range of scan rates. The potential was swept with different rates $(20,50,80$, and $100 \mathrm{mV} \mathrm{s}^{-1}$ ) in the cathodic direction from $0.3 \mathrm{~V}$. The recorded voltammograms are presented in Figure 5. The bulk deposition potentials independent of the scan rate indicate that the reaction is reversible. However, the potentials for UPD and alloying are influenced by this increase. The two cathodic peaks $\mathrm{C}_{2}$ and $\mathrm{C}_{3}$ merge to become one peak with larger current intensity at the scan rate of $100 \mathrm{mV} \mathrm{s}^{-1}$. The merge is accompanied by a shift toward more cathodic potentials. This shift reveals that adsorption is controlled by diffusion. At low scan rates, the ions have sufficient time for diffusion, whereas this is not possible at faster scan rates. 
A cyclic voltammogram recorded under the same condition as Figure 5, but with a lower scan rate (5 and $10 \mathrm{mV} \mathrm{s}^{-1}$ ) is provided in Figure 6. As can be seen, the currents for both reduction and corresponding oxidation peaks increase from the first to the second cycle. In the first cycle, Si deposits on the surface of solid copper, forming a shallow melt, which enhances both adsorption and bulk deposition occurring in the second cycle.

\section{F. Effect of Si Concentration}

As discussed earlier, the deposition potential is a function of Si activity in the product. According to the results of cyclic voltammetry the deposited $\mathrm{Si}$ interacts with the $\mathrm{Cu}$ cathode and forms a $\mathrm{Cu}-\mathrm{Si}$ alloy. During the deposition process, the concentration of $\mathrm{Si}$ in the alloy constantly changes, which results in continuous change in the deposition potential. To investigate this effect, $\mathrm{Si}$ was deposited from cryolite- 6 wt pct $\mathrm{SiO}_{2}$ on the surface of $\mathrm{Cu}$ at $-1.2 \mathrm{~V}$ in two 20 minutes intervals and cyclic

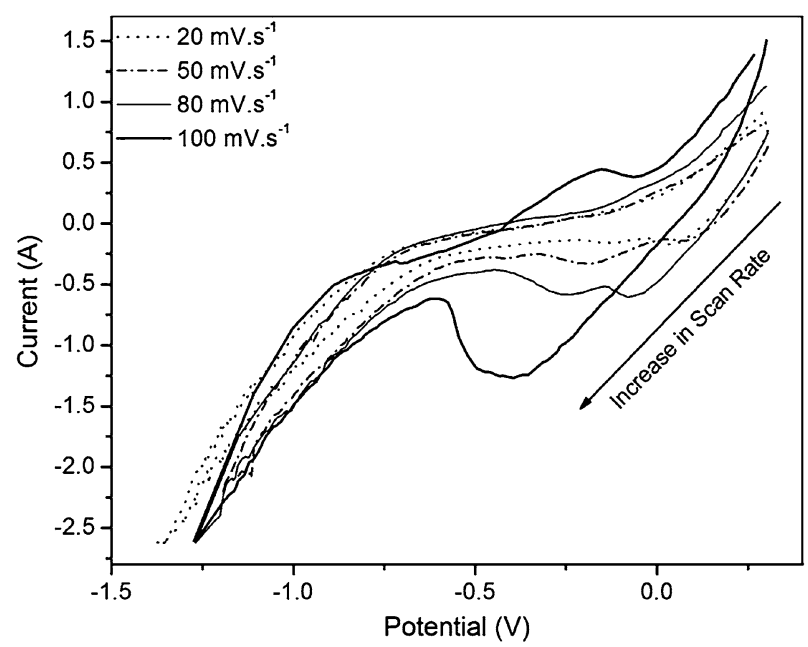

Fig. 5-Effect of scan rate on the recorded voltammogram in cryolite-6 wt pct $\mathrm{SiO}_{2}$ melt, scan rates $20,50,80,200 \mathrm{mV} \mathrm{s}^{-1}$.

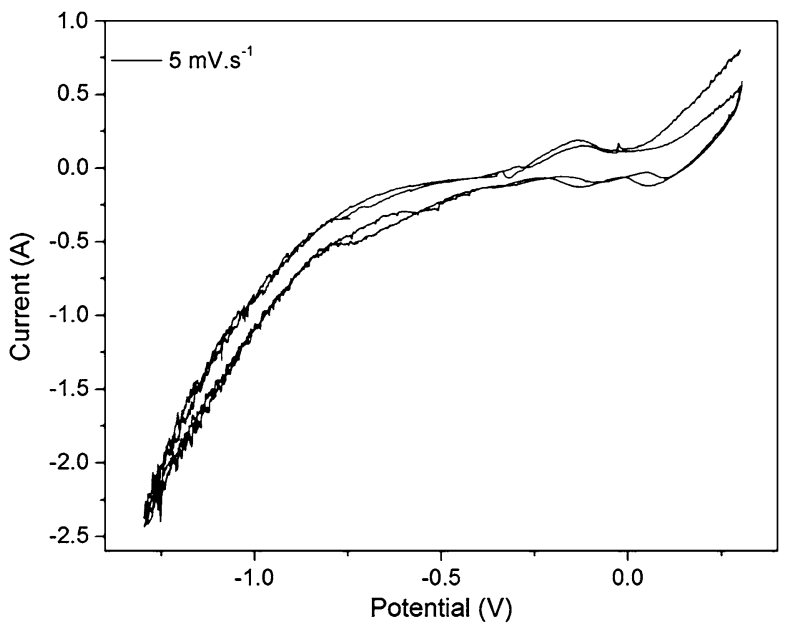

(a) voltammetry was conducted on the surface of the formed alloy after each step. The recorded voltammograms at 20 and $50 \mathrm{mV} \mathrm{s}^{-1}$ scan rates are presented in Figure 7.

As shown in both graphs, increase in Si concentration due to longer deposition time shifts the reduction peaks to more cathodic potential or toward the predicted standard potential. This shift should be considered during the deposition process either by adjusting potential in a certain period of time or applying larger overpotential.

Besides the change in potential, both anodic and cathodic currents increase with higher Si concentration. This change in the kinetics can be due to transformation of solid $\mathrm{Cu}$ to molten $\mathrm{Cu}-\mathrm{Si}$ alloy.

\section{G. SEM Analysis}

The feasibility of depositing $\mathrm{Si}$ was studied by analyzing the cathode after two-step deposition at $-1.2 \mathrm{~V}$. The surface of the cathode was cleaned from solidified electrolyte and was studied under SEM. The image of the sample as well as th elemental mapping is presented in Figure 8. The elemental mapping verifies deposition of Si particles, which are uniformly distributed in $\mathrm{Cu}$. This distribution confirms that the deposited $\mathrm{Si}$ dissolves in copper and forms an alloy. The formed $\mathrm{Cu}-\mathrm{Si}$ alloy is molten at this temperature resulting in formation of a liquid layer on the surface. This surface melting is responsible for change in the shape of the cathode from cylindrical to semi hemispherical shape.

\section{H. Voltammetry Measurements on Copper-8 wt pct Si Alloy}

The electrochemical behavior of the melt on the surface of a Cu-8 wt pct $\mathrm{Si}$ alloy was investigated. The recorded voltammogram is presented in Figure 9. Comparing these two voltammograms reveals the UPD and alloying at 0.15 and $0.04 \mathrm{~V}$. Bulk deposition starts at lower potential of $-1.1 \mathrm{~V}$ compared to pure copper cathode (Figure 4). One other main difference between

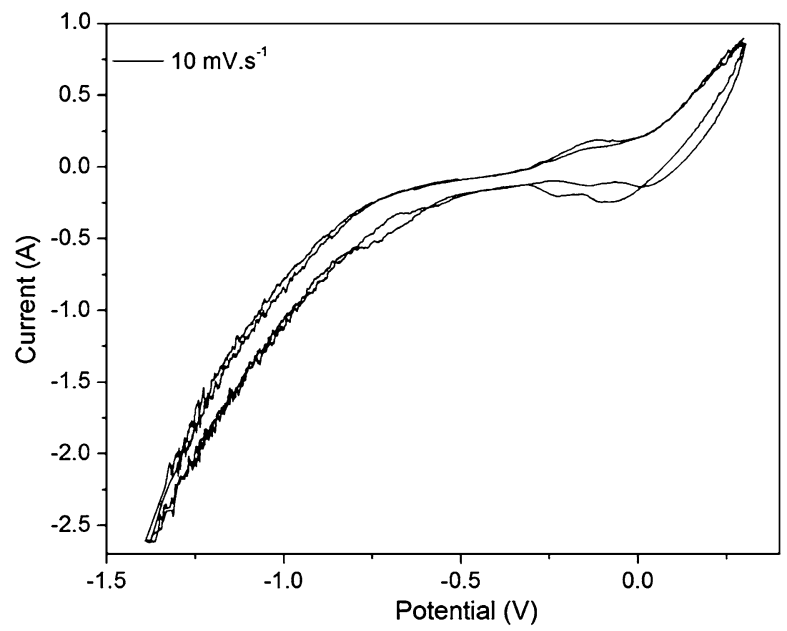

(b)

Fig. 6-Recorded voltammogram in cryolite- 6 wt pet $\mathrm{SiO}_{2}$ melt at scan rates of 5 and $10 \mathrm{mV} \mathrm{s}{ }^{-1}$. 


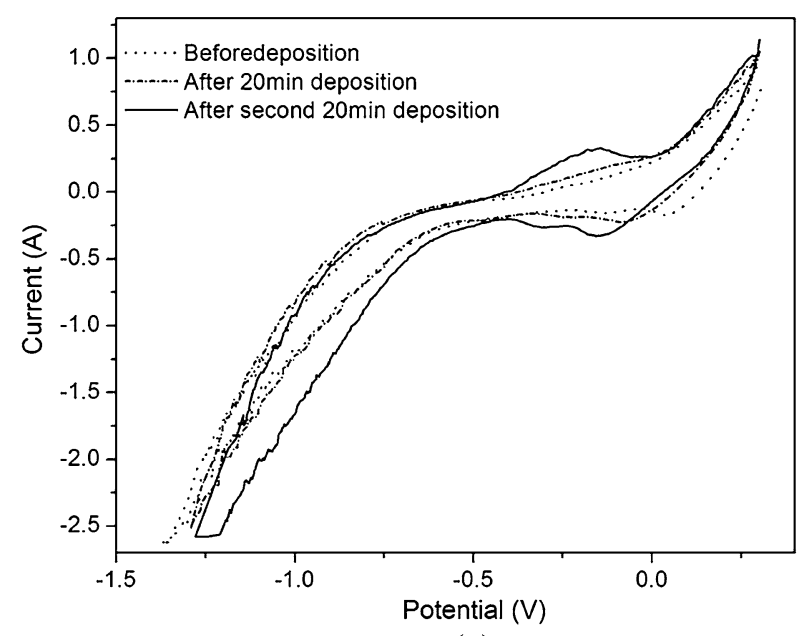

(a)

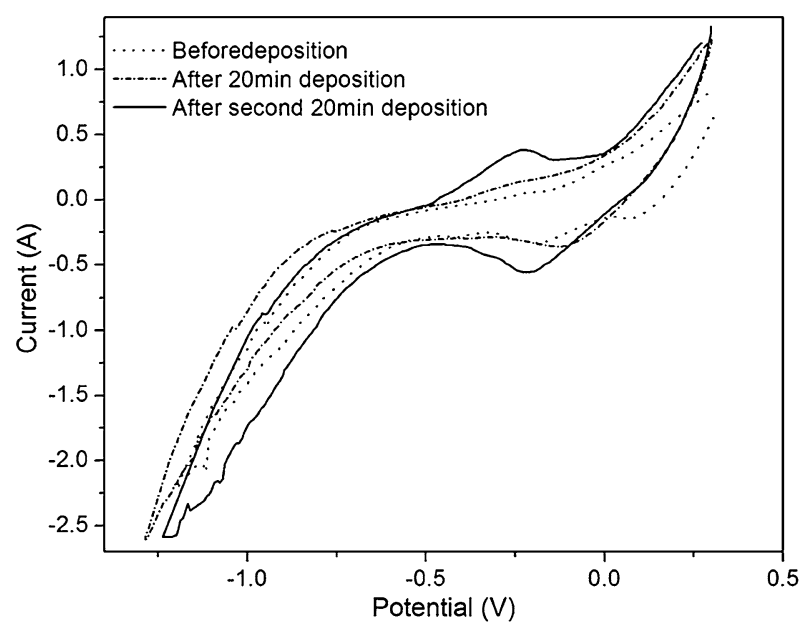

(b)

Fig. 7 - Cyclic voltammogram recorded in cryolite- 6 wt pct $\mathrm{SiO}_{2}$ after two-deposition steps of $20 \mathrm{~min}$; (a) scan rate $20 \mathrm{mV} \mathrm{s}{ }^{-1}$, (b) scan rate $50 \mathrm{mV} \mathrm{s}^{-1}$.
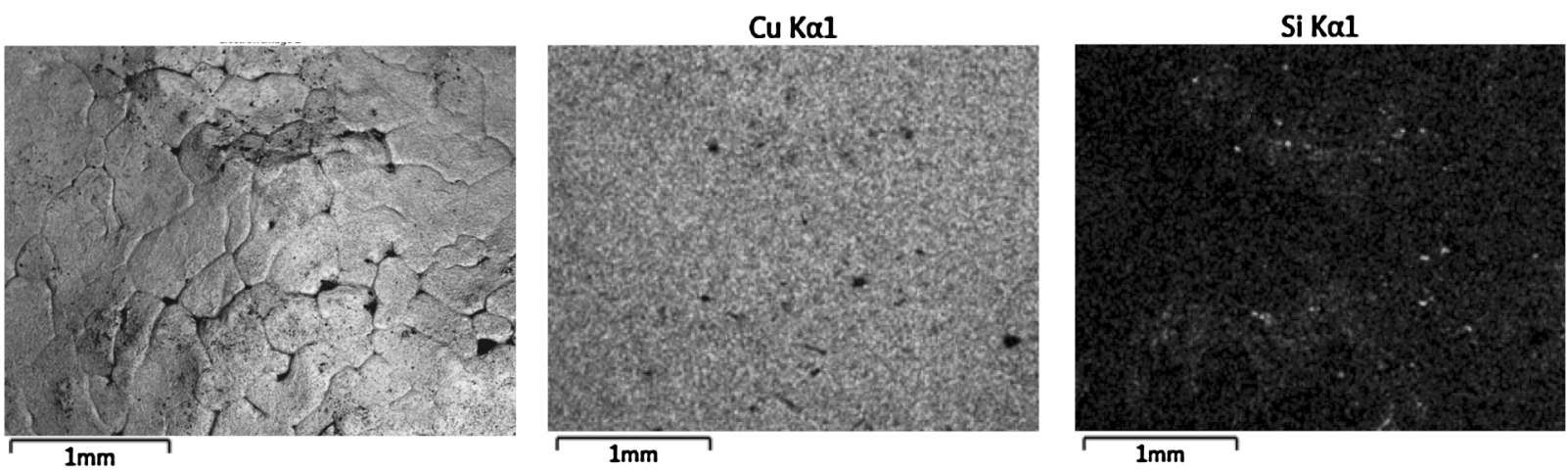

Fig. 8-SEM image and elemental mapping of cathode after 40 min electrolysis at $-1.2 \mathrm{~V}$.

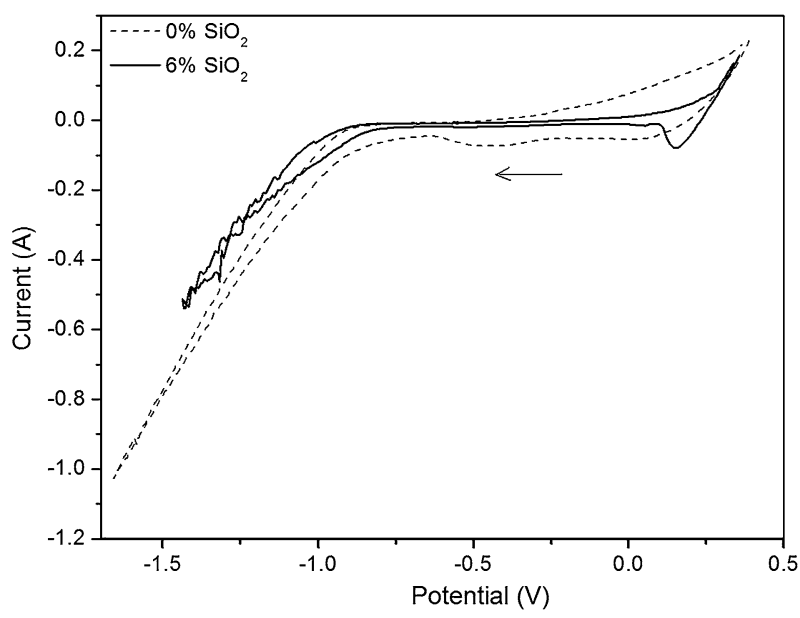

Fig. 9-Voltammogram on $\mathrm{Cu}-8 \mathrm{wt}$ pct $\mathrm{Si}$ in molten cryolite6 wt pet $\mathrm{SiO}_{2} ; 50 \mathrm{mV} \mathrm{s}^{-1}$.

this graph and Figure 4 is the anodic peaks $\left(\mathrm{A}_{2}\right.$ and $\left.\mathrm{A}_{3}\right)$ corresponding to dealloying and stripping of adsorbed $\mathrm{Si}$ does not happen on the surface of $\mathrm{Cu}-\mathrm{Si}$ alloy indicating that these reactions are not reversible. $\mathrm{Cu}-\mathrm{Si}$ alloy is molten at this working temperature, which means that the deposited silicon dissolves in the bulk of cathode immediately, whereas in the experiments involving pure $\mathrm{Cu}$ cathode, the deposited $\mathrm{Si}$ forms a monolayer or solid layer that later strips off in the reverse cycle.

\section{CONCLUSIONS}

The deposition potential of $\mathrm{Si}$ on graphite electrode was measured at approximately $-1 \mathrm{~V}$. This is the required potential that has to be applied to graphite $v s$ $\mathrm{Pt}$ for the continuous deposition of Si. It was found that the kinetics of $\mathrm{Si}$ deposition on graphite is slow, so electrodeposition in molten cathode was considered as a possible solution. Copper was chosen as the candidate cathode, expecting the formation of a liquid $\mathrm{Cu}-\mathrm{Si}$ alloy. The results showed that UPD of Si and formation of $\mathrm{Cu}-\mathrm{Si}$ alloy take place. This was associated to the lower activity of $\mathrm{Si}$ due to its dissolution in $\mathrm{Cu}$. The bulk deposition of $\mathrm{Si}$ on $\mathrm{Cu}$ occurs approximately at $-1 \mathrm{~V}$. Increase in $\mathrm{Si}$ concentration did not change the bulk deposition potential, while shifted the underpotential 
peaks toward the predicted standard potential, possibility as a result of increase in silicon activity. SEM analysis on the cathode after 40 minutes deposition confirmed uniform distribution of $\mathrm{Si}$ at the $\mathrm{Cu}$ surface. The voltammetry on the surface of molten $\mathrm{Cu}-\mathrm{Si}$ alloy confirms $-1.1 \mathrm{~V}$ as the bulk deposition potential of $\mathrm{Si}$. Both underpotential and alloying effect are also observed on this cathode but these reactions are irreversible.

\section{REFERENCES}

1. Silicon Times: Market Review, www.silicontimes.com/en/market/, Accessed 15 Sept 2013.

2. S.S. Hegedus and A. Luque: in Handbook of Photovoltaic Science and Engineering, A. Luque and S. Hegedus, eds., Wiley, West Sussex, 2005, pp. 1-43.

3. A. Müller, M. Ghosh, R. Sonnenschein, and P. Woditsch: Mater. Sci. Eng., B, 2006, vol. 134, pp. 257-62.

4. PVinsights: PV Poly Silicon Weekly Spot Price, pvinsights.com, Accessed 15 Sept 2013.

5. B.R. Bathey and M.C. Cretella: J. Mater.Sci., 1982, vol. 17, pp. 3077-96.

6. J.R. Mott, J.A. Bragagnolo, and M.P. Hayes: in 2010 35th IEEE Photovoltaic Specialists Conference (PVSC), pp. 002147-50.

7. A.F.B. Braga, S.P. Moreira, P.R. Zampieri, J.M.G. Bacchin, and P.R. Mei: Sol. Energy Mater. Sol. Cells, 2008, vol. 92, pp. 418-24.

8. M. Johnston, L. Khajavi, M. Li, S. Sokhanvaran, and M. Barati: JOM, 2012, vol. 64, pp. 935-45.

9. W. Blum and G.W. Vinal: ECS Trans., 1934, vol. 66, pp. 359-67.

10. S. Sokhanvaran and M. Barati: J. Electrochem. Soc., 2014, vol. 161 (1), pp. E1-E6.
11. C.W. Bale, E. Bélisle, P. Chartrand, S.A. Decterov, G. Eriksson, K. Hack, I.H. Jung, Y.B. Kang, J. Melançon, A.D. Pelton, C. Robelin, and S. Petersen: CALPHAD, 2009, vol. 33, pp. 295-311.

12. G.M. Rao, D. Elwell, and R.S. Feigelson: J. Electrochem. Soc., 1981, vol. 128, pp. 1708-11.

13. G. Boe, K. Grjotheim, K. Matiasovsky, and P. Fellner: Can. Metall. Q., 1971, vol. 10, pp. 281-85.

14. G. Boe, K. Grjotheim, K. Matiasovsky, and P. Fellner: Can. Metall. Q., 1971, vol. 10, pp. 179-83.

15. R. Monnier and D. Barakat: Helv. Chim. Acta, 1957, vol. 40, pp. 2041-45.

16. R. Monnier and P. Grandjean: Helv. Chim. Acta, 1960, vol. 43, pp. 2163-72.

17. J.D. Mackenzie: J. Chem. Phys., 1960, vol. 32, pp. 1150-52.

18. G.M. Rao, D. Elwell, and R.S. Feigelson: J. Electrochem. Soc., 1980, vol. 127, pp. 1940-44.

19. K.S. Osen, A.M. Martinez, S. Rolseth, H. Gudbrandsen, M. Juel, and G.M. Haarberg: ECS Trans., 2010, vol. 33, pp. 429-38.

20. R. Boen and J. Bouteillon: J. Appl. Electrochem., 1983, vol. 13, pp. 277-88.

21. J. Ming, L. Yan-Qing, T. Zhong-Liang, L. Fang-Yang, L. Jie, X. Peng-Fei, and L. Ye-Xiang: Acta Phys. Chim. Sin., 2011, vol. 27, p. 7.

22. R. Monnier and J.C. Giacometti: Helv. Chim. Acta, 1964, vol. 47, p. 345 .

23. K. Grjotheim, K. Matiasovsky, P. Fellner, and A. Silny: Can. Metall. Q., 1971, vol. 10, pp. 79-82.

24. R. Monnier and D. Barakat: US Patent no. US3219561 A, 1965.

25. D.B.R. Monnier and J.C. Giacometti: US Patent no.US3254010 A, 1966.

26. S. Sokhanvaran and M. Barati: ECS Trans., 2013, vol. 53 (19), pp. 33-45.

27. D. Liu, Z. Yang, W. Li, S. Wang, and S. Wang: J. Solid State Electrochem., 2011, vol. 15, p. 615.

28. H. Gerischer, D.M. Kolb, and M. Przasnyski: Surf. Sci., 1974, vol. 43 (2), p. 662.

29. L.F. Li, Y. Luo, G.G. Totir, D.A. Totir, G.S. Chottiner, and D.A. Scherson: J. Phys. Chem. B, 1998, vol. 103, p. 64. 